\title{
A New Activated Water Charged by Electrophoresis, Effect on the Experimentally Immuno-Suppressed Animal and Their Anti-Oxidative Activity
}

\author{
Yasuteru Eguchi1 ${ }^{*}$, Nobuo Yamaguchi'1,2, Nurmuhamamt Amat ${ }^{3}$, Dilxat Yimit ${ }^{3}$, \\ Parida Hoxur ${ }^{4}$, Kei Yokokawa ${ }^{1}$ \\ ${ }^{1}$ Ishikawa Natural Medicinal Products Research Center, Ishikawa, Japan \\ ${ }^{2}$ Department of Fundament Research for CAM, Kanazawa Medical University, Ishikawa, Japan \\ ${ }^{3}$ Traditional Uighur Medicine Department, Xinjiang Medical University, Urumqi, China \\ ${ }^{4}$ Traditional Chinese Medicine Hospital, Xinjiang Medical University, Urumqi, China \\ Email: ${ }^{*}$ yas-tel@zpost.plala.or.jp
}

Received 14 May 2015; accepted 25 August 2015; published 28 August 2015

Copyright (C) 2015 by authors and Scientific Research Publishing Inc.

This work is licensed under the Creative Commons Attribution International License (CC BY).

http://creativecommons.org/licenses/by/4.0/

c) (i) Open Access

\begin{abstract}
Every individuals expose to the lisk of conventional immunodeficiency in daily life with both internal and externals. In a series of investigation, we have been assessed the various health promoting menu such as hot spring hydrotherapy, acupuncture \& moxibution, light excurse, evidenced Control water western medicine technique. In this report, we try to investigate the regulatory effect of hydrotherapy by activated water molecule as our representative menu under the influence of hypothalamus system. We set up both animal and human model for assessment of hydrotherapy. Before starting experimental assessment, six males and females seven-week-old ddY mice, are used for the acute oral toxicity study. There is no sign for toxicity as judged by body weight, organ inspection by veterinary doctor. Next, young ddY mice are experimentally induced diabetes and immune-deficient status by administrating cancer chemotherapeutic agent, Streptzotosin. Charged Water was evident to control the blood sugar level compared to the Control Water group together with conventional control group. Both experimental group of mice wear statistically significant for recovery from blood sugar level and antibody secreting cell both IgM and IgG plaque-forming cell. We confirm also activated water group delivered the granulocyte that slow down the oxidative stress by super oxide.
\end{abstract}

\section{Keywords}

New Charged Water, Hydrotherapy, Peripheral Leukocyte, Leukocyte Subsets Ratio, Diabetes

\footnotetext{
${ }^{*}$ Corresponding author.
}

How to cite this paper: Eguchi, Y., Yamaguchi, N., Amat, N., Yimit, D., Hoxur, P. and Yokokawa, K. (2015) A New Activated Water Charged by Electrophoresis, Effect on the Experimentally Immuno-Suppressed Animal and Their Anti-Oxidative Activity. World Journal of Neuroscience, 5, 122-132. http://dx.doi.org/10.4236/oji.2015.53012 


\section{Introduction}

In Japan, around $25 \%$ of the population is over 60 year old people. In aged people, diabetes meritus and acquired immune-deficiency brought depressive and reduction in Quality of Life (QOL). Any trials have been made as health prompting menu. The water itself has been known elsewhere in the world and served as historically and regionally. However, almost all of them are provided as non-data based manner. Here we try to show the special charged water with some evidence-based manner by the western medicine. This water is specially charged by magnetic resonance system, and has been taking for a therapeutic treatment of the health promoting supplement. However, induced the well known adverse reactions such as hypertension and other syndrome such in senile have been popular in world-wide. Therefore, we need safer supplement that are allowed to use for long-term therapy without any adverse reactions in digestive organs. Then, development of a new type of a health supplement that consists of foods and produces anti-oxidative and analgesic activities will be requested. The authors have already developed a new health water supplement, SRE. In this report, we would like to present the efficacy of Charged Water as health supplement in order to know the clinical efficacy (blood sugar level and anti-oxidative activity) of Charged Water. It is assessed by giving to normal animal as well human subjects as health promoting supplemental water. As a result, Charged Water promotes regulative activity for leukocyte subsets in number, blood sugar level and anti-oxidative activities. The popularity of complementary and alternative medicine (CAM) is an international trend in cancer therapy. Due to the severe side effects and limitation of their therapeutic efficacy of anticancer chemotherapeutic agents in the conventional cancer treatment, CAM will be expected to be able to improve clinical outcome and to reduce adverse reaction of anticancer drugs. The World Health Organization says that an estimated $80 \%$ of people worldwide are interested in traditional medicine.

It is well known in natural defense system, there are two primary systems: innate and adaptive. The innate and adoptive do not seem to guard or even prevent the development of one internal threat to survival, but direct sometimes to autoimmunity accompanying hypersensitivity. However, every individuals in the world expose to the lisk of immunodeficiency in daily life with both internal and externals. The factors that influence the acquired immune activity are systemic metabolic disorder such in diabetes meritus, malnutrition, extreme stress, senile and side effect by cellular activity in cancer cell [1]-[12]. So we have to select appropriate menu to regulate immune function through leukocyte storage. The menu has been summarized and listed as CAM: complementary and alternative medicine [13]-[18].

Throughout the world, the phenomenon of the natural hot hydro therapy spawns in the central Asia and East Asia and Europe. Mongolia has a long history of so-called immersion therapy recorded in Chinese or Mongolian medical works. In Gallo-Roman France, a most important number of documents, coins, various china, and votive stones survive from the province of Aquitaine. Even after two thousand years the therapeutic qualities of several mineral hot waters springs of that era are still recognized. This impressive history expands up into Germany, the Netherlands and through the whole of middle and Eastern Europe, extending as far as the well-known bathing centers and customs of Turkey. Japanese geological position on the edge of the Pacific Plate has given it volatile underpinnings, and are always changing and bursting forth in volcanic and earthquake activity. The legacy of this activity is the plethora of hot springs scattered all through its abundant islands. For centuries, these hot springs have been therapeutic destinations for the islands' inhabitants.

Traditionally, such in CAM has its own character and efficacy for various complaints. Through the years, each water source was evaluated for its specific properties and with the advent of better transportation in our mountainous land, even remote springs in the mountains were visited for their specific medicinal effect. For example, the hot spring of Fukatani, which is located just below our research facility, was known all over the area to cure hemorrhoids. However, almost all the judgments of efficacy are VAS (visual analog scale). The proprietors of the hot spring inns say that many of the guests came to cure that sort of ailment since about 20 years ago. Now in Japan, hot spring hydrotherapy is often used as a supplementary therapy for many diseases [19]-[21]. It has shown to reduce surgical complaints such as shoulder pain, amyloidosis and various rheumatic problems. It can also lighten the burden to the heart and improve the condition of patients who suffer from em- 
physema as well as other respiratory ailments. Hot springs have also traditionally functioned as places to relax and enjoy oneself, even though resort-type hot springs always exist along with those for illnesses. In recent years, trends have been seen that even remote hot springs, such as the one below our facility, transform into fashionable resorts for the healthy to visit for relaxation and stress release. It is interesting to note that this historical duplicity encompassed by hot springs has also entered the world of Western medicine as the release of mental stress and physical fatigue has been shown to be essential for good health. Put into other words: the relaxation side of the hot spring promotes prevention, including health enhancement, and the medicinal side, the treatment of illness. In our investigation, we measured the number of leukocyte subsets, granulocyte and lymphocytes regulated before and after hot spring hydrotherapy. Moreover, every individual expose to the lisk of immunodeficiency in daily life with both internal and externals stimuli. In this report, we tried to report the suitable menu for regulate the immune system modulate and discuss how we can compare and select each menu by evidence-based manner more than VAS.

The major purpose of this script is concern with the following issues. One is to confirm the effect of hot spring hydrotherapy within a short time is crucial or not. In other words, the reputational results are possible or not. The regulation was constitution/condition dependent manner and regulate the ideal value to each individual from the condition before the menu. The second was that this regulatory bias was coincides with other factors influenced by pituitary nervous system, such as emotional hormone and the hormone receptor positive lymphocyte. The third one was reputational effect can express linear function and could compared each other with the value of slope. We tried to discuss more, the possibility of the exhibition and comparison between, each menu and established medicine in East and West. The results showed that these subsets could reflect the number and function of immuno-competent cells. For example, in an individual with a low granulocyte number, the number increased after treatment, while it decreased in another individual with a higher cell number. Our results led us to believe that leukocyte subsets could be an interesting indicator for the evaluation of alternative therapies. Many systems are in place to evaluate Western therapies that aim at healing the symptoms of an illness. However, when the purpose of a therapy is to enhance the QOL of healthy people, such as some alternative medical therapies, it is not widely-accepted. Evaluation system has been established. To fill this lack, we would like to propose the umber and functions of leukocyte subsets as indicators for the evaluation of alternative therapies.

\section{Subjects and Methods}

\subsection{Single and Multiple Dose Toxicity Study}

Ten female seven-week-old ddY mice, were used for the acute oral toxicity study. The tests were carried out according to Ethics of the Organization for Economic Co-operation and Development (OECD) Test Guideline 401. The mice were housed at $24^{\circ} \mathrm{C} \pm 11^{\circ} \mathrm{C}, 50 \%$ relative humidity. Both Conventional and Charged Water were suspended in sterile and administered to mice in free supplemental system, calculating daily consumption. Mice were weighted at 0 - 7 days after administration, and clinical observations were made once a day. Necropsy was performed on all mice seven days after administration.

\subsection{Experimental Design for Bone Marrow Suppressed Immune-Compromised Mice}

In the animal model of immuno-competency reduction, male C57BL/6J mice, aged 8 - 9 weeks, were injected with Mitomycin-C (MMC) (5 mg/kg) to inhibit the bone marrow. Then, Charged Water was administered orally and the Conventional Water was set up as control [22] (Figure 1, Figure 2).

\subsection{Regulation of Total Leukocytes Number}

The bone marrow-suppressed mice were administered herbal decoction FBT 1g/kg dairy for 5 days and after 1 week later, their blood were withdrawn from their tail vain. Then, the number of leukocytes was counted in Bürker-Türk solution.

\subsubsection{Regulation of Leukocyte Subsets}

Bone marrow-suppressed mice were administered with Conventional Water and Charged Water for 30 days. One week later, the blood from their tail vain was withdrawn. Then the granulocyte and lymphocyte subsets 
were counted in Bürker-Türk solution.

\subsubsection{Regulation of CD Positive Cells}

Cells from peritoneal exudates were collect from the peritoneal cavity of bone marrow-suppressed mice. Phagocytes were purified using adherent technique to get cell suspensions which contained more than $95 \%$ of phagocytes. The purified cells were loaded to the upper room of Boyden chamber to test migration ability at a concentration of $1 \times 10^{4} \mathrm{cell} / \mathrm{ml}$. Human serum treated at $56^{\circ} \mathrm{C}$ for $30 \mathrm{~min}$ was for the chemo tactic agent of mouse phagocyte [23].

\subsubsection{Regulation of Cytokine Producing Cells}

The same cells suspension was purified by adherent technique for phagocyte, which produces cells contained more than $95 \%$ of phagocytes. The purified cells were adjusted to $1 \times 10^{4} \mathrm{cell} / \mathrm{cm}^{2}$ and mixed with latex beads that are $5 \mu \mathrm{m}$ in granule with fluorescence isocyanate. After $90 \mathrm{~min}$ of incubation, remained granule were washed out from the glass slide. Number of phagocytic cell and their ability to catch up the latex beads were automatically measured by ACAS system, which outputs the result in a digital form (Adeherent cell activity evaluating system; Shimazu, Kyoto, Japan).
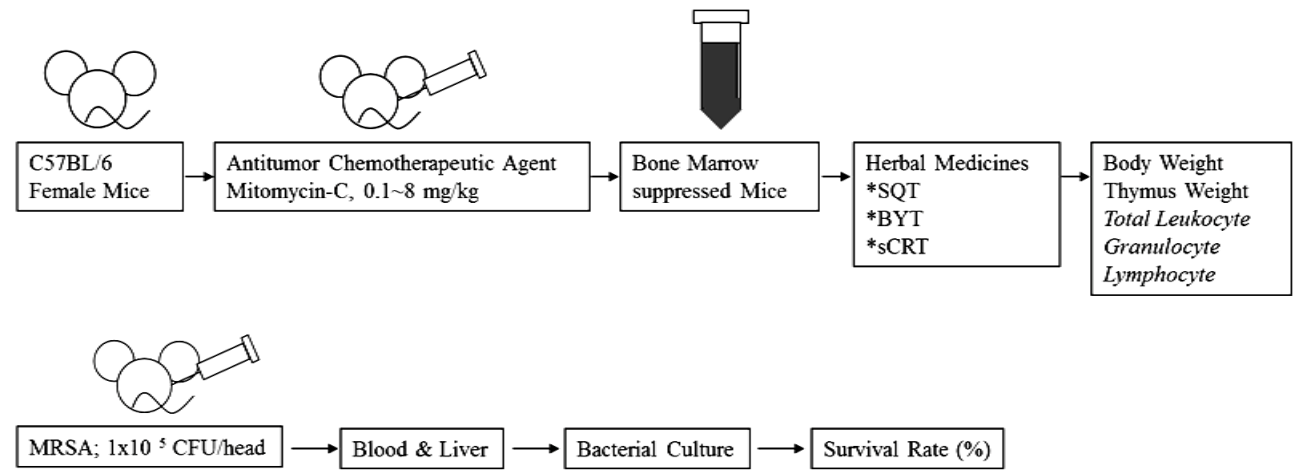

Figure 1. Experimental design for access the Charged Water for Immuno Compromised host in Mice. We sampled peripheral blood from the 12 volunteers before and after hot hydro therapy, at the same time on each day, in accordance with the consideration of circadian rhythm of leukocyte. The spring quality is a weak sodium chloride with sodium carbohydrate of the water temperature $40 \pm 1 \mathrm{C}$. During the night and in the morning of the next day, they had a bath in the hot spring two or three times, for 20 - 30 minutes each time. Time interval of blood sampling between before and after hot-spring hydrotherapy was approximately 24 hours. The total and differential leukocyte counts were measured control water he automated hematology analyzer.

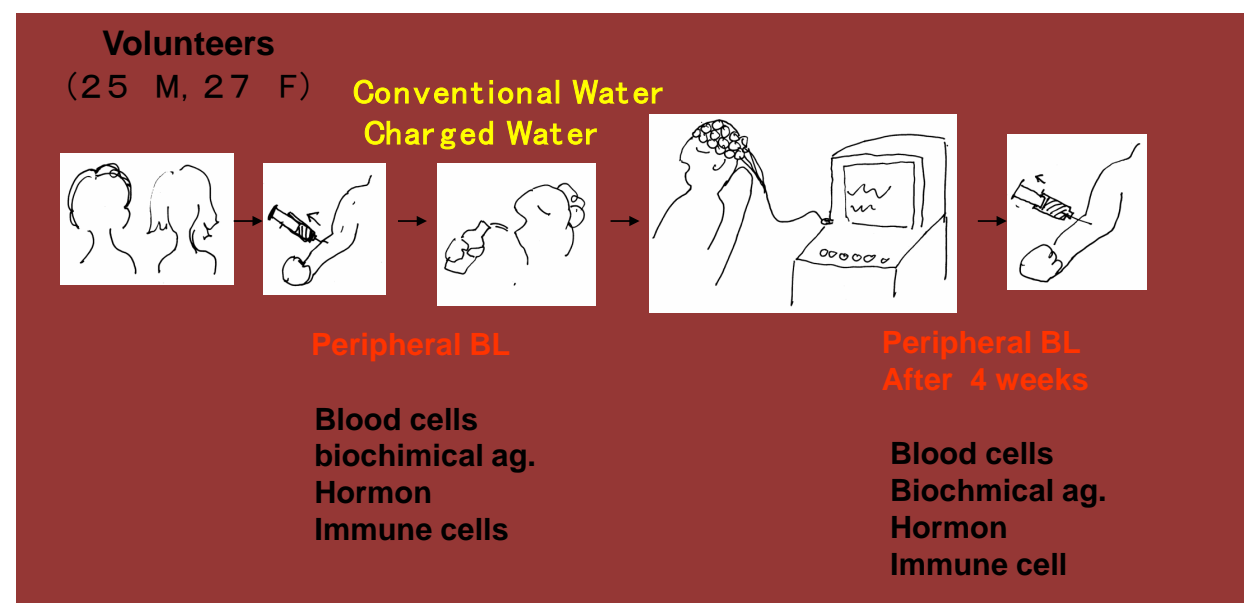

Figure 2. Experimental design for access the Charged Water for Immuno Compromised host in Human. We tried to express the effect of peripheral total leukocyte number by individual level of change and plot in the $\mathrm{x}$-axis as in each age. Variations in leukocyte subpopulations in the peripheral blood before and after hot spring hydrotherapy. 


\subsubsection{Regulation of Lymphocyte Activity, Antibody Secreting Cell}

The bone marrow suppressed mice were administered herbal decoction of FBT ( $1 \mathrm{~g} / \mathrm{kg} / \mathrm{day})$ for 5 days. Oneweek later, mice were immunized with sheep red blood cells, $\left(2 \times 10^{8} /\right.$ mouse $)$ intraperitoneally. Five days later, their spleen cells were collected. Plague-forming cells (PFC) were developed, and the ability of IgM and IgG antibody production was tested Charged Water, method reported by Jerne and Nordin [24].

\subsubsection{Regulation of CD Positive Lymphocyte Distribution by Charged Water against Different Constitution}

Whole blood obtained from the subjects was washed twice with PBS. One hundred micro-liters of the suspensions were stained with $20 \mu \mathrm{l}$ of fluorescent monoclonal antibodies (anti-human $\mathrm{CD} 2^{+}, \mathrm{CD} 4^{+}, \mathrm{CD}^{+}, \mathrm{CD} 11 \mathrm{~b}^{+}$, $\mathrm{CD}_{14}^{+}, \mathrm{CD}^{2} 6^{+}, \mathrm{CD}_{19}{ }^{+}$and $\mathrm{CD}^{+}{ }^{+}$antibodies). Ten thousands stained cells were re-suspended in PBS to detect surface markers by flow cytometry (FACS Calibur; Becton Dickinson Immnocytometry Systems, CA, USA).

\subsubsection{Distribution of Cytokine Producing Lymphocytes in Different Constitution}

The blood cell suspensions were cultured with PMA (phorbol 12-myristate 13-acetate), ionomycin and BSA (bovine serum albumin) for $4-5$ hours at $37^{\circ} \mathrm{C}$. After that, the cell suspensions were stained using the monoclonal antibodies of PE-IL-4, FITC-IFN- $\gamma$ and FITC-IL- $1 \beta$. Then they were analyzed by The FACScan (Becton Dickinson Co. Ltd. U.S.A.). The antibodies and reagents used in the test were purchased from Becton Dickinson Immunocytometry system (USA).

\subsection{Animals}

Eight week-old female C57BL/6 were purchased from Sankyo Laboratory Service Corporation (Shizuoka, Japan). All mice were kept under specific pathogen-free conditions. Mice food and distilled water were freely accessible for each mouse. Housing temperature and humidity were controlled $25^{\circ} \mathrm{C} \pm 1{ }^{\circ} \mathrm{C}$ and $60 \%$.

\subsubsection{Reagents}

As for the basic medium, HEPES buffer (HEPES $17 \mathrm{mM}$, NaCl $120 \mathrm{mM}$, Glucose $5 \mathrm{mM}, \mathrm{KCl} 5 \mathrm{mM}, \mathrm{CaCl}_{2} 1$ $\mathrm{mM}, \mathrm{MgCl}_{2} 1 \mathrm{mM}$ ) was prepared and sterilized by filtration. Phorbol 12-myristate 13-acetate (PMA, Sigma, USA) was diluted to $10^{-6} \mathrm{M}$ by dimethyl sulfoxide DMSO, Sigma, USA) and used as a stimulant for super oxide anion generation for murine peritoneal exudates cells. Cytochrome-c (Sigma, USA) was diluted to $1 \mathrm{mM}$ by HEPES buffer. Since cytochrome-c reduced by super oxide showed maximum absorbance at $550 \mathrm{~nm}$, we used cytochrome-c to measure the amount of super oxide anion generation through spectro-photometrical technique. Oyster glycogen (type II, Sigma, USA) was diluted in the purified water $(10 \% \mathrm{w} / \mathrm{v}$, Wako, Japan) and autoclaved at $120^{\circ} \mathrm{C}$ for 20 mins. This solution was used for intraperitoneal injection to mice in order to induce peripheral neutrophils into the abdominal cavity [25].

\subsubsection{Measuring the Amount of Super Oxide Anion Generated by Murine Peritoneal Exudates Cells} Each drug was orally administered to mice (500 mg/kg) for one week. Two milliliters of $10 \%$ Oyster glycogen was injected intraperitoneally 10 hours before the assay. Sufficient murine peritoneal xadate cells were induced ten hours after the stimulation. Mice were euthanized by cervical dislocation, murine peritoneal exudates cells (PEC) suspension was centrifuged twice for 5 minutes at $1500 \mathrm{rpm}$ at $4^{\circ} \mathrm{C}$. Then PEC was prepared to $1 \times 10^{6}$ cells/ml of HEPES buffer. One hundred microliters of cytochrome-c and $10 \mu \mathrm{l}$ of PMA were added to the cell suspension and this was incubated for 20 minutes at $37^{\circ} \mathrm{C}$. The reaction mixture was then centrifuged for 10 minutes at $1500 \mathrm{rpm}, 4^{\circ} \mathrm{C}$. An OD of supernatant was measured at both $550 \mathrm{~nm}$ and $540 \mathrm{~nm}$, the amount of generated super oxide anion was shown in the formula; increased absorbance at $550 \mathrm{~nm}\left(\Delta \mathrm{A}_{550-540}\right) / 19.1 \times 10^{3}$ $(\mathrm{mmol} / \mathrm{ml})$. In order to ensure if we really measured the amount of generated super oxide anion or not, we tried to add super oxide anion dismutase (SOD), an enzyme for its anti-oxidative effect, into our experimental system. The result was as expected that the reduction of Cytochrome-c was inhibited after the addition of SOD. This showed us that our experimental system could be used properly for measuring the amount of generated super oxide anion.

\subsection{Statistical Analysis}

Data are expressed as means \pm standard deviations. The differences between FBT-treated and non-treated condi- 
tions were compared using a one-tailed analysis of variance. A $P$ value $<0.05$ was considered to be statistically significant.

\section{Results}

\subsection{Mice System}

\subsubsection{Single Dose and Multiple Dose Toxicity Study of Conventional Water and Charged Water}

No deaths or abnormalities of body weight, water and food consumption, or coat condition were observed in the treated mice. Necropsy evaluation of the mice did not reveal any significant differences in thymus, liver, spleen, kidney, adrenal gland and testicle weights between the control group and both control water and charged and activated water.

\subsubsection{A Measuring the Amount of Super Oxide Anion Generated by Murine Peritoneal Macrophage} Each group of mice was orally administered freely from administrating bottle for one month. At the day for assay, two $\mathrm{ml}$ of $10 \%$ Oyster glycogen was injected intraperitonealy about 10 hours before the assay. Sufficient murine peritoneal exudate cells were induced ten hours after the stimulation (data not shown). Mice were euthanized by cervical dislocation, murine peritoneal exudate cells (PEC) suspension was centrifuged twice for 5 minutes at $1500 \mathrm{rpm}, 4^{\circ} \mathrm{C}$. Then PEC was prepared to $1 \times 10^{6}$ cells $/ \mathrm{ml}$ of HEPES buffer. One hundred $\mu \mathrm{l} \mathrm{cytoch-}$ rome-c and $10 \mu \mathrm{l}$ PMA were added to the cell suspension and this was incubated for 20 minutes at $37^{\circ} \mathrm{C}$. The reaction mixture was then centrifuged for 10 minutes at $1500 \mathrm{rpm}, 4^{\circ} \mathrm{C}$. OD of supernatant was measured at both $550 \mathrm{~nm}$ and $540 \mathrm{~nm}$, the amount of generated super oxide anion was shown in the formula; increased absorbance at $550 \mathrm{~nm}\left(\Delta \mathrm{A}_{550-540}\right) / 19.1 \times 10^{3}(\mathrm{mmol} / \mathrm{ml})$ [25] (Figure 3, Figure 4).

\subsubsection{Experimental Model for Diabetes Meritus and the Effect of Hydrotherapy}

Each group of ddY mice (female 8w-old) were administered Streptozotosin (STZ) in order to induced experimental diabetes meritus. Then each mice was orally administered freely for one mon The rate of diabetes model mice acquisition which can be used for an examination is about $50 \%$.

Tail vein injection of STZ containing physiological saline solution was carried out at the control group.

STZ-Sterilization distilled water is given to a contrast group.

The influence of hydrotherapy was tested by employing the glucose tolerance-ability with orally loading (Table 1, Table 2).

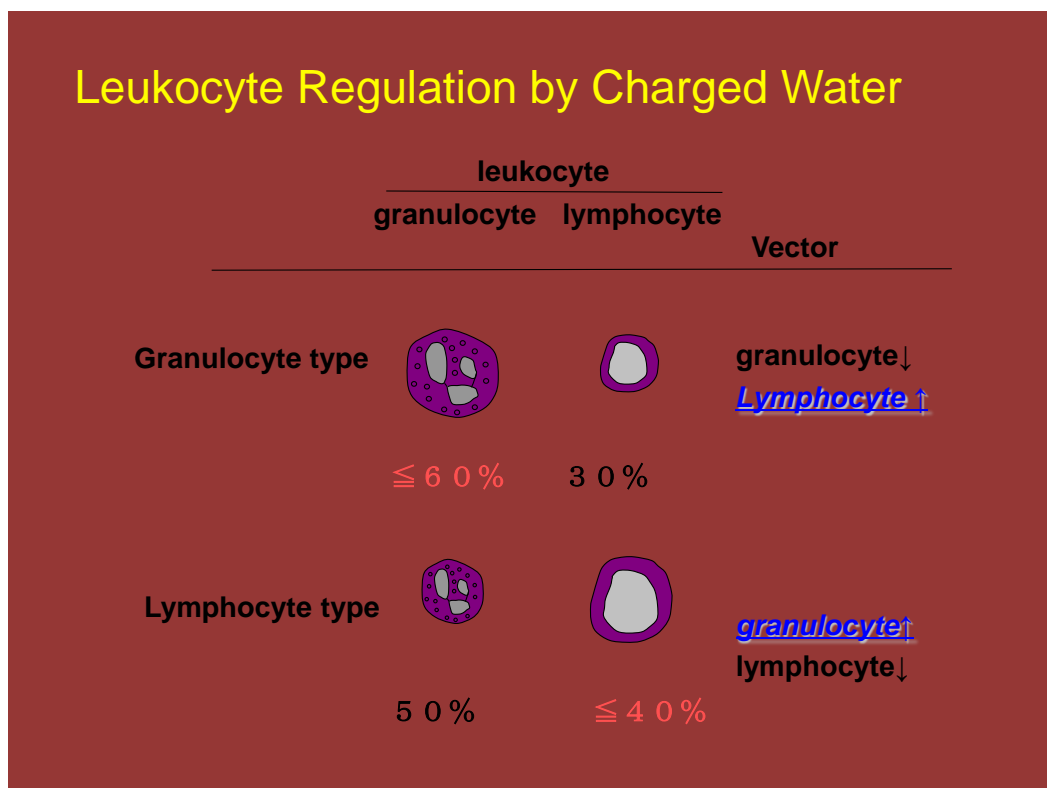

Figure 3. Leukocyte Regulation by Charged Water. We sampled peripheral blood from the 12 volunteers before and after hot spring hydrotherapy, at the same time on each day, in accordance with the consideration of circadian rhythm of leukocyte in this figure, we tried to show the date simply pooled and make mean, then compared. 


\subsubsection{Changes in Cell Number of Total Leukocyte and Subsets}

Leukocyte numbers have been counted one hour before and 15 days after the treatment of hemopoietic formula. The cell number measured one hour before the administration was set as $100 \%$. Relative percentage of cell number on the 15th day was calculated. No significant changes were observed in G-group after the administration of control water. However, significant change was found in L-type group (Table 1).

\subsection{Dividing Subjects into Two Groups, G-Type and L-Type by Granulocyte and Lymphocyte Proportion}

The volunteers were healthy subject, with no drastic change for the total number of leukocytes. However, we tried to check the regulative effect of herbal formulae for two different constitution, G-rich type and L-rich type. Analysis that mixed both groups together showed no significant differences in total leukocyte number except that for HF; in G-type group, total number of leukocytes was down regulated by Charged water. This was a results of the down regulation of major group of leukocyte, granulocyte.

As for the L-type, no significant changes were found after the treatment of both HFs. In the L-type group, Charged Water, on the other hand, increased the tonal leukocyte and granulocyte in number, on the contrary to the down regulation for lymphocytes. To further clarify the influence of hemopoietic formula, we divided the subjects into two groups: the G-type group, who had a granulocyte count over $60 \%$, and the L-type group, who

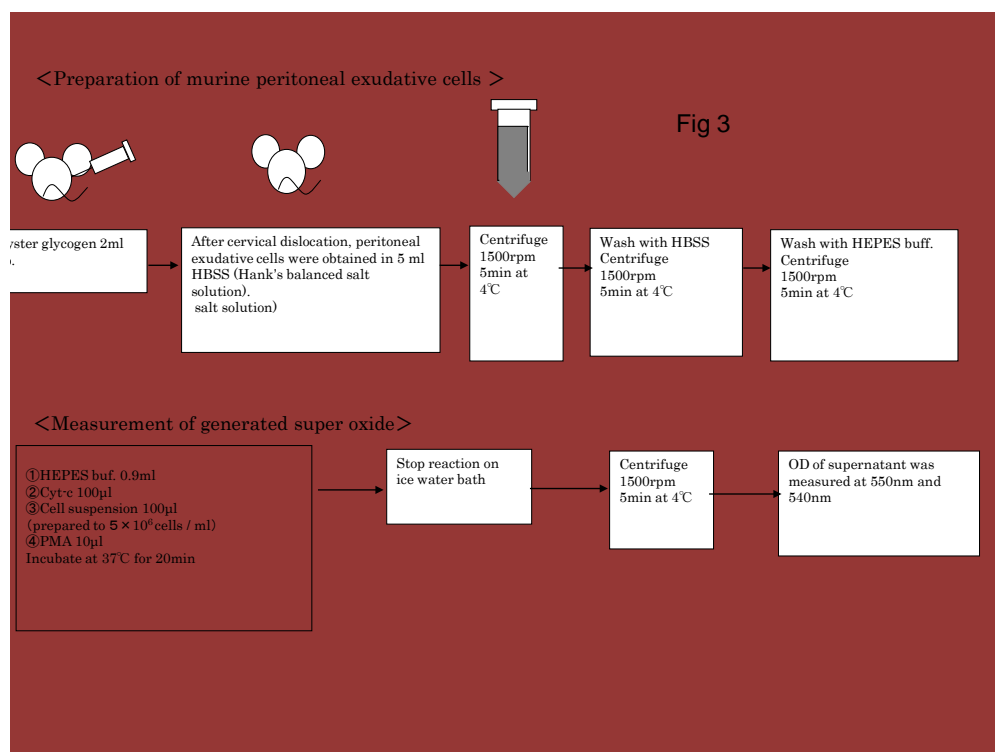

Figure 4. Protocol for Assessing the Effect by Charged Water for Anti-oxidative Activity in Macrophage. Each spot were obtained from the calculation comparing relative value from before and after levels in the serum, catecholamines levels in the peripheral blood. The constitution dependent analysis, the detail change and vector of each change could find from individual data, showing higher value volunteer down regulated much more than lower leveled one.

Table 1. Constitution dependent regulation of leukocyte Charged Water.

\begin{tabular}{|ccccc}
\hline & \multicolumn{2}{c}{ G-type individual } & \multicolumn{2}{c}{ L-type individual } \\
\hline & \multicolumn{2}{c}{ Conv. Water } & \multicolumn{2}{c|}{ Charged Water } \\
\hline & Before & After & Before & After \\
\hline Total WBC $\left(\times 10^{3} \mu 1\right)$ & 6.26 & 5.79 & 3.45 & 5.67 \\
Lymphocyte (\%) & 23.7 & 25.8 & 43.1 & 42.5 \\
Granulocyte (\%) & 65.5 & 65.7 & 56.7 & 57.8 \\
Neutrophil (\%) & 64.6 & 52.4 & 45.7 & 51.3 \\
\hline
\end{tabular}


had a lymphocyte count over $40 \%$. In the L-type group, lymphocyte counts tended to decrease on day 15, accompanied by an increase in granulocyte numbers by Charged Water but not by Conventional Water. On the contrary, the granulocyte counts of G type group tended to decrease on day 15 . The decrease of granulocyte count was raised by Conventional Water but not by Charged Water on day 15.

\subsection{Lymphocyte Subsets Showed Significant Variation}

After HF treatment, cell counts of $\mathrm{CD}_{2}^{+}, \mathrm{CD}^{+}, \mathrm{CD}^{+}, \mathrm{CD} 1 \mathrm{~b}^{+}, \mathrm{CD} 16^{+}, \mathrm{CD} 19^{+}$and $\mathrm{CD} 56^{+}$were tested to evaluate variations in $\mathrm{T}$ cells, $\mathrm{B}$ cells, macrophages and NK cells. These values were measured one hour before hemopoietic formula and 15 days thereafter. Our results showed that CD2 and CD4 cells were increased by both Conventional Water and Charged Water $\mathrm{CD} 11 \mathrm{~b}^{+}$and $\mathrm{CD} 14^{+}$cell counts, which are closely associated with macrophage activity, increased by Conventional Water in the L-type subjects. In particular, there was a remarkable increase in $\mathrm{CD}_{11} \mathrm{~b}^{+}$cell number on day 15 . $\mathrm{T}$ cell subsets that are closely associated with activity of immature $\mathrm{T}$ cells, $\left(\mathrm{CD}^{+}, \mathrm{CD}^{+}\right.$and $\left.\mathrm{CD}^{+}\right)$, the $\mathrm{CD}^{+}(P<0.05)$ showed an increase with the treatment of Conventional Water and Charged Water 15 days after administration. The number of $\mathrm{CD}_{19^{+}}$cells, which is closely associated with B cell activity, was not changed by both HF throughout the trial, neither were the numbers of $\mathrm{CD} 16^{+}$and CD56 ${ }^{+}$cells (Table 2).

\subsection{Cytokine Producing Cells}

To test whether herbal decoction affected the functional maturation of immunocytes in a short time, we investigated the number of cytokine producing/containing cells by FACS analysis. This method reveals cytokine producing cell number by peering off the surface of lymphocyte, enable to express the number of cells in festival evening, compare than serum cytokine level that correspond to the paper tips of post festival. To determine whether HF influences functional maturation of immuno-competent cells, levels of IL-1 $\beta$-, IL-4- and IFN- $\gamma$-expressed $\mathrm{T}$ cells were further examined using fluorescence-activated cell sorter analyses. There was a significant increase in the levels of IFN- $\gamma$ and IL-4 containing cells after administration of Charged Water. The result revealed that IFN- $\gamma$ expression, which increased highly on the 15th day after treatment, was different from the expression of IL-1 $\beta$ and IL-4, those on the other hand, exponentially increased on day 15 after the administration of Charged Water. The augmentation of cytokine expression was confirmed by a classical method in the lymphoid organ, i.e. antibody-forming cells and plaque-forming cells. Both HFs down-regulated IL-1 $\beta$ producing cells in both G-type and L-type groups (Table 3).

\subsection{Antibody Forming Cell Study by Parented Charged Water}

Sheep erythrocyte (SRBC), a T-dependent antigen, was used for antibody formation cell study. Ten days after

Table 2. Constitution dependent regulation of CD Positive Cell by Charged Water.

\begin{tabular}{ccccc}
\hline & \multicolumn{2}{c}{ G-type individual } & \multicolumn{2}{c}{ L-type individual } \\
\cline { 2 - 5 } CD & \multicolumn{2}{c}{ Conv. Water } & \multicolumn{2}{c}{ Charged Water } \\
\cline { 2 - 5 } & Before (\%) & After (\%) & Before (\%) & After (\%) \\
\hline CD2 & 62.67 & 74.76 & 62.25 & 78.56 \\
CD4 & 20.34 & 29.87 & 32.34 & 46.56 \\
CD8 & 39.68 & 41.57 & 24.21 & 28.76 \\
CD11 & 73.54 & 71.77 & 63.65 & 73.57 \\
CD14 & 0.04 & 0.07 & 0.06 & 0.07 \\
CD16 & 64.44 & 57.56 & 55.65 & 50.76 \\
CD19 & 8.56 & 8.98 & 8.45 & 7.99 \\
CD56 & 1.76 & 1.77 & 1.67 & 2.65 \\
\hline
\end{tabular}


tumor transplantation, each antigen was intra-peritoneally injected. After four and six days, the antibody-forming cells were detected using localized hemolysis in an agar gel. Plaque-forming cells were developed by the method of Jerne and Nordin [24].

The fermentation is proceeded by bacterial digestion and degradation, less of the efficient constituents would be lost than commonly used extraction by hot water. Therefore we decided to ferment the herbal medicine by yeast (Saccharomyces cerevisiae), expecting the enhancement of lymphocyte activating effects through antibody forming cells. The antibody forming cells after one week's administration of fermented Conventional Water and Charged Water were 135\% and 140\%, respectively. All the fermented herbal medicines from HF increased PFC (Table 4).

\section{Discussion}

Every creature in the world including human exposes to the lisk of immunodeficiency in daily life [26]. The factors that influence the acquired immune activity are systemic metabolic disorder such in diabetes meritus, malnutrition, extreme stress, senile and side effect by cellular activity in cancer cell. So we have to select daily an appropriate menu to regulate immune function through leukocyte storage. The menu has been summarized and listed as CAM: complementary and alternative medicine. One of the major menu is Charged Water in western medicine world, some trying o integrate Western Medicine and Eastern Medicine.

We have been trying to regulate the immune responsiveness through much mature for fragile daily condition from circumstance stress and so on. The main menu is acupuncture, hotspring hydrotherapy, light exercise etc. In this article, we would like to show the regulatory mechanism of the hot spring hydrotherapy. The circumstance, the balneotherapy using the effectiveness of the hydrotherapy, except for cases of contraindication, has been medically useful approved to be effective in many stress-related disorders and the improvement of dysfunction of the biological rhythm disturbance as well as chronic disease. The mechanism of effects has been reported in many studies, but many things are still unclear. Balneotherapy needs to be treated in general a period of time, but the effectiveness has been suggested even if the short duration hot-springs hydrotherapy. We examine the effect of hot spring hydrotherapy for a short duration on immune system and report about the quantitative and qualitative variation of immuno-competent cells [27]. The mechanism is suggested the association with an autonomic nervous system and the endocrine system. Hot spring hydrotherapy for a short duration is expected to stimulate sympathetic nerve or parasympathetic nerve and to change the levels of catecholamines (adrenalin, noradrenaline, and dopamine), which are neurotransmitters and hormones, as well as the number and function of immune cells.

\section{Table 3. Constitution dependent regulation of Cytokine Producing Cell by Charged Water.}

\begin{tabular}{ccccc} 
& \multicolumn{2}{c}{ G type individual } & \multicolumn{2}{c}{ L type individual } \\
\cline { 2 - 5 } Cytokine & \multicolumn{2}{c}{ Conv. Water } & \multicolumn{2}{c}{ Charged Water } \\
\cline { 2 - 5 } & Before (\%) & After (\%) & Before (\%) & After(\%) \\
\hline IFN- $\gamma$ & 6.87 & 5.33 & 3.46 & 5.45 \\
IL-4 & 1.6 & 1.7 & 2.8 & 3.8 \\
IL-1 $\beta$ & 0.9 & 0.7 & 0.8 & 1.3 \\
\hline
\end{tabular}

Table 4. Plaque Forming/Antibody Secreting Cell.

\begin{tabular}{cc} 
Group Number & PFC/10 ${ }^{\mathbf{6}}$ Spleen Cells \\
\hline 1 Normal Mice & $348 \pm 461$ \\
2 MMC Control & $58 \pm 54$ \\
3 MMC + Conventional Water & $71 \pm 21$ \\
4 MMC + Charged Water & $296 \pm 55^{*}$ \\
\hline
\end{tabular}

\footnotetext{
${ }^{*} \mathrm{p}<0.05$ comparing to MMC control.
} 
Our results showed that within 24 hours after hot spring hydrotherapy, the white blood cells in peripheral blood had changed significantly, not only in cell count but also cell function. We hoped that our work would attract more attention to the mechanisms of which hot spring hydrotherapy regulates the human immune system. Abo reported that according to the lymphocyte subset content, lymphocyte rich type showed over $40 \%$ on the other hand granulocyte rich type show over 60\% of granulocyte [17]-[30]. Each type exhibited different character even in the same age, sexuality and each age. In the figure, within the same age and the sex, even in mankind could sort out as G-rich type (granulocyte 60\%), and L-rich type (lymphocyte $40 \%$ ). On the other hand, as a stand point of sex difference, the ladies belonged to L-rich type but the man belonged to G-rich type. According to the age-related change, G-rich type of man changed to L-rich type within the same sex.

\section{References}

[1] Kurashige, S., Yoshida, T. and Mitsuhashi, S. (1980) Immune Response in Sarcoma 10-Bearing Mice. Annual Report of Gunnma University, 1, 36-44.

[2] Miyazaki, S. (1977) Immunodificiency in Clinical Origin. Clinical Pediatrics, 1001-1006.

[3] Kishida, K., Miyazaku, S., Take, H., Fujimoto, T., Shi, H., Sasaki, K. and Goya, N. (1978) Granial Irradiation and Lymphocyte Subpopulation in Acute Lymphatic Leukemia. Journal of Pediatrics, 92, 785-786. http://dx.doi.org/10.1016/S0022-3476(78)80155-3

[4] Yamaguchi, N., Takei, T., Chen, R., Wushuer, P. and Wu, H.W. (2013) Maternal Bias of Immunity to Her Offspring: Possibility of an Autoimmunity Twist out from Maternal Immunity to Her Young. Open Journal of Rheumatology and Autoimmune Diseases, 3, 40-55. http://dx.doi.org/10.4236/ojra.2013.31008

[5] Murgita, R.A. and Tomasi Jr., T.B. (1975) Suppression of the Immune Response by Alpha-Fetoprotein. The Journal of Experimental Medicine, 141, 269-286. http://dx.doi.org/10.1084/jem.141.2.269

[6] Paul, G., Margaret, S., Liew, Y.F. and Allan, M.M. (1995) $\mathrm{CD}^{4+}$ But Not $\mathrm{CD}^{8+}$ T Cells Are Required for the Induction of Oral Tolerance. International Immunology, 7, 501-504. http://dx.doi.org/10.1093/intimm/7.3.501

[7] Koshimo, H., Miyazawa, H.Y., Shimizu, Y. and Yamaguchi, N. (1989) Maternal Antigenic Stimulation Actively Produces Suppressor Activity in Offspring. Developmental \& Comparative Immunology, 13, 79-85. http://dx.doi.org/10.1016/0145-305X(89)90020-7

[8] Zoeller, M. (1988) Tolerization during Pregnancy: Impact on the Development of Antigen-Specific Help and Suppression. European Journal of Immunology, 18, 1937-1943. http://dx.doi.org/10.1002/eji.1830181211

[9] Auerback, R. and Clark, S. (1975) Immunological Tolerance: Transmission from Mother to Offspring. Science, 189, 811-813. http://dx.doi.org/10.1126/science.1162355

[10] Shinka, S., Dohi, Y., Komatsu, T., Natarajan, R. and Amano, T. (1974) Immunological Unresponsiveness in Mice. I. Immunological Unresponsiveness Induced in Embryonic Mice by Maternofetal Transfer of Human-Globulin. Biken Journal, 17, 59-72.

[11] Aase, J.M., Noren, G.R., Reddy, D.V. and Geme Jr., J.W. (1972) Mumps-Virus Infection in Pregnant Women and the Immunologic Response of Their Offspring. The New England Journal of Medicine, 286, 1379-1382. http://dx.doi.org/10.1056/NEJM197206292862603

[12] Cramer, D.V., Kunz, H.W. and Gill III, T.J. (1974) Immunologic Sensitization Prior to Birth. American Journal of Obstetrics \& Gynecology, 120, 431-439.

[13] Yamaguchi, N., Hashimoto, H., Arai, M., Takada, S., Kawada, N., Taru, A., Li, A.-L., Izumi, H. and Sugiyama, K. (2002) Effect of Acupuncture on Leukocyte and Lymphocyte Subpopulation in Human Peripheral Blood-Quantitative discussion. The Journal of Japanese Association of Physical Medicine, Balneology and Climatology, 65, 199-206.

[14] Wan, W., Li, A.-L., Izumi, H., Kawada, N., Arai, M., Takada, A., Taru, A., Hashimoto, H. and Yamaguchi, N. (2002) Effect of Acupuncture on Leukocyte and Lymphocyte Subpopulation in Human Peripheral Blood Qualitative discussion. The Journal of Japanese Association of Physical Medicine, Balneology and Climatology, 65, 207-211.

[15] Wang, X.-X., Katoh, S. and Liu, B.-X. (1998) Effect of Physical Exercise on Leukocyte and Lymphocytes Subpopulations in Human Peripheral Blood. Cytometry Research, 8, 53-61.

[16] Kitada, Y., Wan, W., Matsui, K., Matsui, K., Shimizu, S. and Yamaguchi, N. (2000) Regulation of Peripheral White Blood Cells in Numbers and Functions through Hot-Spring Bathing during a Short Term-Studies in Control Experiments. Journal of Japanese Society Balneology Climatology Physiological Medicine, 63, 151-164.

[17] Bylund, D.B., Eikenberg, D.C., Hieble, J.P., Langer, S.Z., Lefkowitz, R.J. and Minneman, K.P. (1994) Intenational union of Pharmacology Nomenclature of Adrenoceptors. Pharmacological Review, 46, 121-136.

[18] Dulis, B.H. and Wilson, I.B. (1980) The $\beta$-Adrenergic Receptor of Live Human Polymorphonuclear Leukocytes. 
Journal of Biological and Chemistry, 255, 1043-1048.

[19] Ostberg, J.R., Patel, R. and Repasky, E.A. (2000) Regulation of Immune Activity by Mild (Fever-Range) Whole Body Hyperthermia: Effect on Epidermal Langerhans Cells. Cell Stress Chaperones, 5, 458-461. http://dx.doi.org/10.1379/1466-1268(2000)005<0458:ROIABM>2.0.CO;2

[20] Huang, Y.H., Haegerstrand, A. and Frostegard, J. (1996) Effect of in Vitro Hyperthermia on Proliferative Responses and Lymphocyte Activity. Clinical Experimental Immunology, 103, 61-66. http://dx.doi.org/10.1046/j.1365-2249.1996.00932.x

[21] Mats, H., Orion, E. and Wolf, R. (2003) Balneotherapy in Dermatology. Dermatological Therapy, 16, $132-140$.

[22] Elenkov, I.J. and Chrousos, G.P. (1999) Stress Hormones, Th1/Th2 Patterns, Pro/Anti-Inflammatory Cytokines and Susceptibility to Disease. Trends in Endocrinology and Metabolism, 10, 359-368.

[23] Abo, T. and Kumagai, K. (1978) Studies of Surface Immunoglobulins on Human B Lymphocytes. III. Physiological Variations of Sig $^{+}$Cells in Peripheral Blood. Clinical Experimental Immunology, 33, 441-452.

[24] Landmann, R.M.A., Muller, F.B., Perini, C., Wesp, M., Erne, P. and Buhler, F.R. (1954) Changes of Immunoregulatory Cells Induced by Psychological and Physical Stress: Relationship to Plasma Catecholamines. Clinical Experimental Immunology, 58, 127-135.

[25] Yamaguchi, N., Araai, M. and Murayama, T. (2015) Aspect of QOL Assessment and Proposed New Scale for Evaluation. Open Journal of Immunology, in press.

[26] Yamaguchi, N., Kawada, N., Ja, X.-S., Okamoto, K., Okuzumi, K., Chen, R. and Takahashi, T. (2014) Overall Estimation of Anti-Oxidant Activity by Mammal Macrophage. Open Journal of Rheumatology and Autoimmune Diseases, 4, 13-21.

[27] Abo, T., Kawate, T., Itoh, K. and Kumagai, K. (1981) Studies on the Bioperiodicity of the Immune Response. 1. Circadian Rhythms of Human T, B and K Cell Traffic in the Peripheral Blood. Journal of Immunology, 126, 1360-1363.

[28] Jerne, N.K. and Nordin, A.A. (1963) Plaque Formation in Agar by Single Antibody Producing Cells. Science, 140, 405-408.

[29] Maisel, A.S., Harris, T., Rearden, C.A. and Michel, M.C. (1990) Beta-Adrenergic Receptors in Lymphocyte Subsets after Exercise. Alterations in Normal Individuals and Patients with Congestive Heart Failure. Circulation, 82, 20032010. http://dx.doi.org/10.1161/01.CIR.82.6.2003

[30] Suzuki, S., Toyabe, S., Moroda, T., Tada, T., Tsukahara, A. and Iiai, T. (1997) Circadian Rhythm of Leukocytes and Lymphocytes Subsets and Its Possible Correlation with the Function of the Autonomic Nervous System. Clinical Experimental Immunology, 110, 500-508. http://dx.doi.org/10.1046/j.1365-2249.1997.4411460.x

\section{Abbreviations}

CAM: Complementary and alternative medicine, beside the western medicine, there are many traditional medicine and/or health promoting menu all over the world

CD: Cluster of differentiation. Each lymphocyte has name that expressed CD number, for example CD2, CD4, etc.

FCM: Flow cytometry.

G-rich type: The individual that exhibit over $60 \%$ of granulocyte in peripheral blood, finding many in young gentleman.

L-rich type: The individual that exhibit over $40 \%$ of lymphocyte in peripheral blood, finding lot in ladies and senile.

Charged Water: Conventional Water was electrophoretically separated by direct current. Then Charged Water were obtained by both anode side and cathode site.. In this experiment cathode side of water was served as Charged Water.

QOL: Quality of life.

VAS: Visual analog scale. 